\title{
Anti-VP1 and Anti-VP2 Antibodies Detected by Immunofluorescence Assays in Patients with Acute Human Parvovirus B19 Infection
}

\author{
Renata FA Pereira, Walquiria NS de Paula, Rita de Cássia N Cubel, \\ Jussara P Nascimento*/+
}

\begin{abstract}
Departamento de Microbiologia e Parasitologia, Instituto Biomédico, UFF, Niterói, RJ, Brasil *Departamento de Desenvolvimento Tecnológico, BioManguinhos-Fiocruz, Av. Brasil 4365, 21045-900

Rio de Janeiro, RJ, Brasil
\end{abstract}

Acute human parvovirus $B 19$ infection is followed by an antibody response to the structural proteins of the viral capsid (VPI and VP2). We used 80 sera collected from 58 erythema infectiosum and 6 transient aplastic crisis patients to test IgM and IgG antibodies against these two proteins in an immunofluorescence assay (IFA) using Sf9 cells infected with recombinant baculovirus expressing either VPI or VP2 antigen. Although less sensitive than IgM capture enzyme immunoassay using native antigen (MACEIA), we could detect anti-VP1 or anti-VP2 IgM antibodies by IFA in 49 patients with acute infection (76.6\%). Detection of IgG anti-VP1 and anti-VP2 by IFA, however, was as sensitive as IgG detection by indirect enzyme immunoassay. By applying IgG avidity IFA to sera of the 15 IgM IFA negative patients we were able to confirm acute infection in further 12 cases by IFA. Overall, acute infection was confirmed by IFA in 61 (95.3\%) of the 64 patients.

Key words: human parvovirus B19 - VP1 and VP2 structural proteins - IgG and IgM antibodies immunofluorescence - IgG avidity

Infection with human parvovirus B19 is common and has a worldwide distribution. Infection may be asymptomatic or associated to a wide spectrum of disease including erythema infectiosum (EI), transient aplastic crisis (TAC), hydrops fetalis and acquired pure red cell aplasia (Young 1996). Acute infection is followed by an antibody response to the virus and laboratory diagnosis is most often made by detecting specific IgM and IgG antibodies in patient's serum (Anderson et al. 1985). As parvovirus B19 does not grow readily in cell culture, the first assays established to detect anti-B19 IgM antibodies were developed using native virus obtained from viremic plasma of acute phase patients or blood donors (Cohen et al. 1983, Anderson et al. 1986). Later, synthetic peptides (Fridell et al. 1991) and recombinant antigens produced in different protein expression systems (Morinet

\footnotetext{
This work was supported by grants from the Conselho Nacional de Desenvolvimento Científico e Tecnológico (CNPq).

RFAP was recipient of a Capes fellowship.

${ }^{+}$Corresponding author. Fax: +55-21-260.4727. E-mail: jpnascim@bio.fiocruz.br

Received 18 July 2000

Accepted 7 December 2000
}

et al. 1991, Schwarz et al. 1991, Söderlund et al. 1992) were used to replace limited native antigen and avoid the risk of working with infectious antigens. The best expression system has proved to be Spodoptera frugiperda (Sf9) cells and recombinant baculovirus not only because of the high level of antigen achieved (Brown et al. 1990a) but also because empty capsids are formed when the major structural protein, VP2, is expressed either alone or together with the minor structural protein, VP1 (Kajigaya et al. 1991, Brown et al. 1991). During recent years, we have used a native B19 antigen in an in house IgM capture enzyme immunoassay (MACEIA) to diagnosis acute infection (Cubel et al. 1992, 1997, Oliveira et al. 1996). This paper now describes an in house immunofluorescence assay using $\mathrm{Sf} 9$ cells infected with recombinant baculovirus expressing either VP1 or VP2. The assay was used to detect the antibody response against VP1 and VP2 EI and TAC patients.

\section{MATERIALS AND METHODS}

Serum samples - In this study, we used 80 sera collected from 64 patients with EI (58) or TAC (6); 16 sera collected from 13 patients (rash disease $=12$ and $\mathrm{TAC}=1$ ) without acute $\mathrm{B} 19$ infection were also included as controls. The sera had previously been tested for anti-B19 IgM by MACEIA using the native virus as antigen (Cubel et al. 1994) 
and for anti-B19 IgG using baculovirus recombinant capsids (Kajigaya et al.1991) containing VP2 $(70 \%)$ and VP1 (30\%) in a indirect enzyme immunoassay (EIA) (Cubel et al. 1997). All sera were now tested for anti-B19 IgM and IgG using Sf9 cells expressing both VP1 and VP2 by immunofluorescence assay (IFA) as described bellow.

\section{IFA}

Slide preparation - Sf9 cells growing in Hink's medium suplemented with $10 \%$ fetal calf serum were infected with recombinant AcVP1 or AcVP2 (Hicks et al. 1996) at a multiplicity of infection of 10 virus particles per cell. For IgG tests the cells were harvested after $48 \mathrm{~h}$ and after $72 \mathrm{~h}$ for IgM detection. Equal amounts of infected and non-infected cells were mixed and approximately 5,000 cells per well were spotted onto 12-well silane treated slides. After acetone fixation at $4^{\circ} \mathrm{C}$ for 5 min, the slides were dried and stored at $-20^{\circ} \mathrm{C}$ until used. Slide preparations for IFA were standardized using standard human anti-B19 IgM and IgG sera and normal human serum supplied by Virus Reference Division, Central Public Health Laboratory (VRD/CPHL), UK.

Antibody detection by IFA - For IgM all sera were treated with Reumatoid Factor Absorbent (Behring) before being tested. Treated sera (final serum dilution is 1 in 20) were added to different wells and incubated at $37^{\circ} \mathrm{C}$ for $2 \mathrm{~h}$. Slides were washed in phosphate buffered saline (PBS) plus $0.05 \%$ Tween 20 (PBS/T). FITC-conjugated goat anti-human IgM (Behring) was then added and the slides incubated a further $30 \mathrm{~min}$ at $37^{\circ} \mathrm{C}$. For the $\mathrm{IgG}$, serum were diluted in 1 in 20 and incubated 30 $\min$ at $37^{\circ} \mathrm{C}$. After washing with PBS/T, FITC conjugated goat anti-human IgG (Behring) was used.

Antibody avidity test - IgG antibody avidity was examined by the modification of IFA as described by Gray et al. (1993). In this assay serum dilutions from 1 in 10 to 1 in 10240 were applied to duplicate slides with VP1 or VP2 infected Sf9 cells. After a first incubation of $60 \mathrm{~min}$, slides were washed either with PBS containing 6M urea or PBS alone. IgG antibody was considered low avidity when an eight-fold decrease in the antibody titer was found with the urea washed slides compared to those washed without urea (Gray et al. 1993). The percentage of $\mathrm{IgG}$ avidity was calculated by the ratio of the antibody titers (urea+/urea-) x 100 (Söderlund et al. 1995a).

\section{RESULTS}

The distribution of VP1 and VP2 antigen in Sf9 cells examined by IFA, 48 and $72 \mathrm{~h}$ post infection (p.i.), is shown in Fig. 1. We chose to use cells $72 \mathrm{~h}$ p.i. to detect IgM because the sensitivity was higher than when we used cells $48 \mathrm{~h}$ p.i. In contrast, to detect $\mathrm{IgG}$, better discrimination between positive and negative sera was achieved when using cells $48 \mathrm{~h}$ p.i.

IgM detection - Sixty-four patients were studied and from 16 of them two serum samples were available. Fig. 2 shows anti-B19 IgM antibody distribution as detected by MACEIA according to the time of sample collection for the 52 patients where

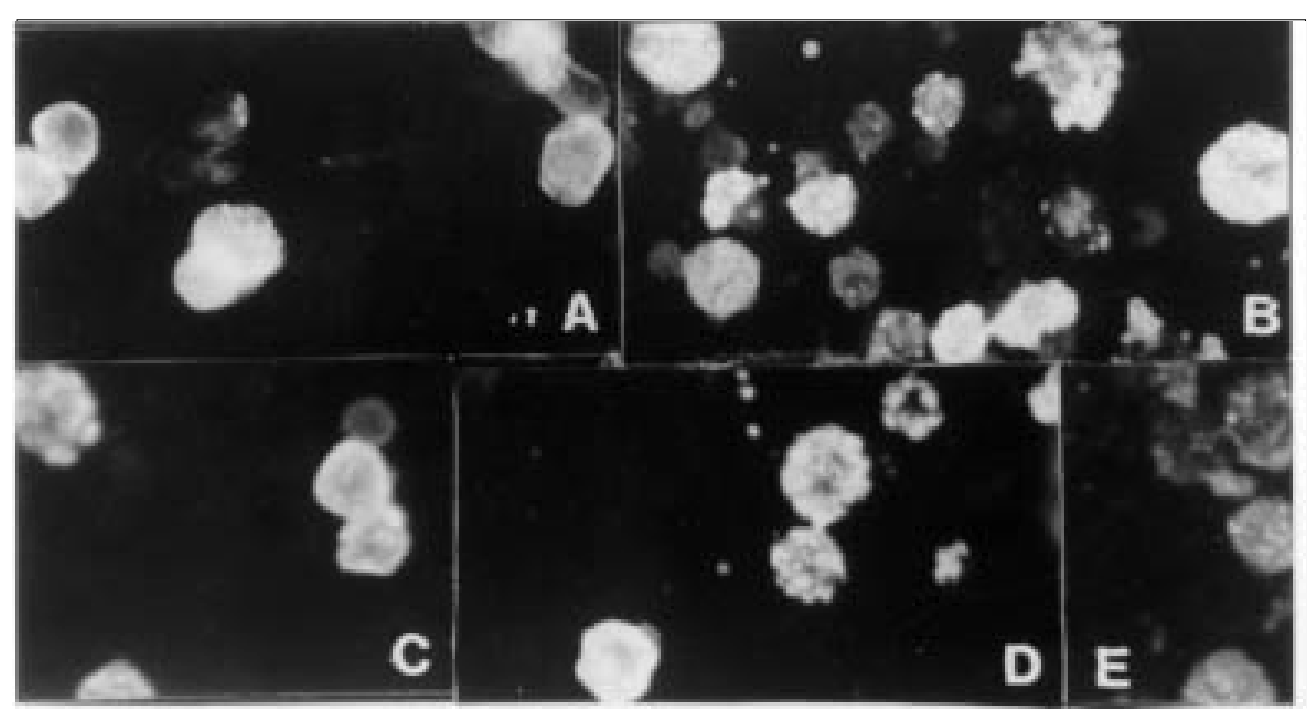

Fig. 1: Sf9 cells expressing VP1 or VP2, as mesured by IFA using standard human serum - IgG anti-B19 (100 u.a. RIA). A: Sf9 cells after $48 \mathrm{~h}$ infection with AcVP1; B: Sf9 cells after $72 \mathrm{~h}$ infection with AcVP1; C: Sf9 cells after $48 \mathrm{~h}$ infection with AcVP2; D: Sf9 cells after $72 \mathrm{~h}$ infection with AcVP2; E: Sf9 cells after $72 \mathrm{~h}$ infection with AcVP1 and IFA using normal human serum (negative control). 
this information was available. Six patients from whom we had two serum samples were negative by MACEIA in one of the two samples collected. Three of these 6 IgM negative samples were collected more than 15 days after disease onset $(16$, 29 and 60 days) and for the other 3 sera these data were not available. From a total of 74 MACEIA positive sera, 52 were IFA positive for IgM antibodies to VP1 and 40 to VP2. Two IFA IgM antiVP1 positive sera were found among the 22 MACEIA negative sera, but none of them was positive for IgM anti-VP2 (Table I). IgM anti-VP2 negative results by IFA were found mainly with sera collected very early ( 1 to 2 days) or those collected more than 6 days after disease onset. For anti-VP1 IgM no correlation was found between IFA results and days after disease onset (Fig. 2). Most of the IFA IgM negative sera, either with VP1 or VP2 antigen, showed low P/N ratios in MACEIA (Table II). Overall, of the 64 acutely-infected patients studied, IgM was detected by IFA in 49 (76.6\%), 35 patients being IgM IFA positive with both VP1 and VP2, 12 patients positive only with VP1, 2 patients positive only with VP2. Fifteen were negative for both antigens. Of 13 controls, 2 were positive for anti-VP1 IgM by IFA.

\section{TABLE I}

Anti-B19 IgM antibodies by MACEIA and IFA in 96 sera collected from 64 acute B19 infections and 13 control cases

\begin{tabular}{lccccccr}
\hline & \multicolumn{2}{c}{ VP1(IFA) } & & \multicolumn{2}{c}{ VP2(IFA) } & \\
\cline { 2 - 3 } MACEIA & Positive & Negative & & Positive & Negativen & Total \\
\hline Positive & 52 & 22 & & 40 & 34 & 74 \\
Negative & 2 & 20 & & 0 & 22 & 22 \\
\hline Total & 54 & 42 & & 40 & 56 & 96 \\
\hline
\end{tabular}

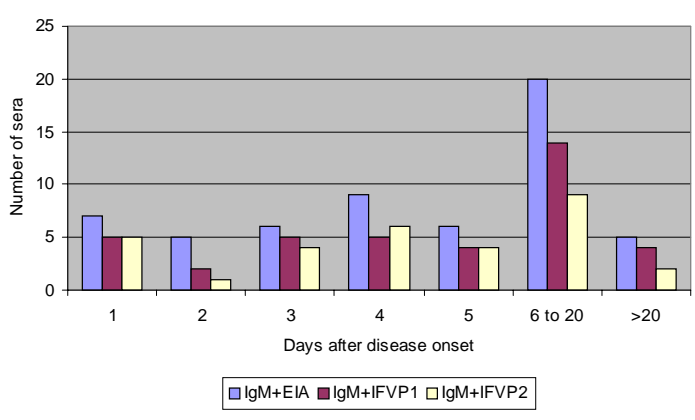

Fig. 2: days after disease onset and detection of anti-B19 IgM antibodies by MACEIA and anti-VP1 and anti-VP2 IgM antibodies by immunofluorescence in 61 sera from 52 patients with recent B19 infection

IgG detection - Of 81 IgG EIA positive sera from patients and controls tested by IFA, all were positive for anti-VP1 IgG and 80 for anti-VP2 IgG. Of $15 \mathrm{IgG}$ EIA negative sera, two were IFA positive, one positive with both VP1 and VP2 and one positive with VP1 only (Table III). IgG EIA P/N ratios for negative and positive sera by IFA is showed in Table IV.

TABLE III

Results of anti-B19 IgG antibodies by EIA and immunofluorescence in 96 sera collected from 64 acute B19 infection and 13 control cases

\begin{tabular}{lcccccrr}
\hline & \multicolumn{2}{c}{ VP1(IFA) } & & \multicolumn{2}{c}{ VP2(IFA) } & \\
\cline { 2 - 3 } \cline { 5 - 6 } EIA & Positive & Negative & & Positive & Negative & Total \\
\hline Positive & 81 & 0 & & 80 & 1 & 81 \\
Negative & $2^{a}$ & 13 & & 1 & 14 & 15 \\
\hline Total & 83 & 13 & & 81 & 15 & 96 \\
\hline
\end{tabular}

$a$ : one of the two EIA negative and VP1 positive sera was also positive to VP2.

TABLE II

Anti-VP1 and Anti-VP2 IgM antibodies by IFA related to P/N values in MACEIA

\begin{tabular}{|c|c|c|c|c|c|}
\hline \multirow{2}{*}{$\begin{array}{c}\text { MACEIA } \\
\text { P/N }\end{array}$} & \multicolumn{2}{|c|}{ VP1 (IFA) } & \multicolumn{2}{|c|}{ VP2 (IFA) } & \multirow[t]{2}{*}{ Total } \\
\hline & Positive & Negative & Positive & Negative & \\
\hline 0-1.9 & 2 & 20 & 0 & 22 & 22 \\
\hline $2.0-3.0$ & 15 & 20 & 8 & 27 & 35 \\
\hline $3.1-5.0$ & 15 & 1 & 15 & 1 & 16 \\
\hline $5.1-10.0$ & 20 & 1 & 15 & 6 & 21 \\
\hline $10.1-20.0$ & 2 & 0 & 2 & 0 & 2 \\
\hline Total & 54 & 42 & 40 & 56 & 96 \\
\hline$X \pm \sigma^{a}$ & $4.9 \pm 2.97$ & $2.0 \pm 1.05$ & $5.4 \pm 3.10$ & $2.5 \pm 1.66$ & \\
\hline
\end{tabular}

$a$ : average and standard deviation for P/N values of the sera in the same class, i.e. VP1 or VP2 positive and negative by IFA 
Ig $G$ avidity - Twenty serum samples from 15 patients IgM positive by MACEIA but negative by IFA with both VP1 and VP2 were tested for IgG antibody avidity to confirm acute infection (Table V). IgG avidity test confirmed acute infection in 12 of the 15 patients. Three of them (cases 4,8 and 12) were confirmed by low IgG antibody avidity with both VP1 and VP2 and 9 were confirmed either with VP1(cases 2, 5, 7, 9, 10 and 14) or VP2 (cases 3, 11 and 13). One other patient (case 15) had only one serum sample collected during a TAC and this sample was IgG negative by IFA with both VP1 and VP2. Sera from two other patients (cases 1 and 6), although $\operatorname{IgG}$ positive by
IFA, had low levels (<80) with both VP1 and VP2 and they could not be confirmed as acute infection by demonstrating low avidity antibody.

Overall, we were thus able to diagnose by IFA $61(95.3 \%)$ of 64 acute B19 infections, 49 by IgM detection and 12 by low avidity IgG.

\section{DISCUSSION}

B19 antibody detection (IgM and IgG) by IFA using baculovirus infected cells expressing VP1 was first described by Brown et al. (1990b). There is now a commercial IFA test developed by Biotrin International Ltd (Ireland) based on VP1 expressed in Sf9 cells. Other commercial assays using recom-

TABLE IV

Anti-VP1 and Anti-VP2 IgG antibodies by IFA related to P/N values in EIA IgG test

\begin{tabular}{|c|c|c|c|c|c|}
\hline \multirow{2}{*}{$\begin{array}{l}\text { EIA } \\
\text { P/N }\end{array}$} & \multicolumn{2}{|c|}{ VP1 (IFA) } & \multicolumn{2}{|c|}{ VP2 (IFA) } & \multirow[t]{2}{*}{ Total } \\
\hline & Positive & Negative & Positive & Negative & \\
\hline 0-2.0 & 2 & 13 & 1 & 14 & 15 \\
\hline $2.1-5.0$ & 56 & 0 & 55 & 1 & 56 \\
\hline $5.1-10.0$ & 24 & 0 & 24 & 0 & 24 \\
\hline 10.1-15.0 & 1 & 0 & 1 & 0 & 1 \\
\hline Total & 83 & 13 & 81 & 15 & 96 \\
\hline $\mathrm{X} \pm \sigma^{a}$ & $4.3 \pm 1.9$ & $1.2 \pm 0.18$ & $4.3 \pm 1.88$ & $1.3 \pm 0.44$ & \\
\hline
\end{tabular}

$a$ : average and standard deviation for P/N values for sera in the same class, i.e., VP1 or VP2 positive and negative by IFA

TABLE V

IgG avidity test results for 20 sera collected from 15 anti-B19 $\operatorname{IgM}$ negative cases by IFA and positive by MACEIA

\begin{tabular}{rcccccc}
\hline Patients & Age & $\begin{array}{c}\text { Clinical } \\
\text { diagnosis }\end{array}$ & $\begin{array}{c}\text { Days after } \\
\text { onset }\end{array}$ & $\begin{array}{c}\text { Anti-VP1 } \\
\text { IgG titer }\end{array}$ & $\begin{array}{c}\text { Anti-VP2 } \\
\text { IgG titer }\end{array}$ & $\begin{array}{c}\text { Antibody } \\
\text { avidity(\%) } \\
\text { VP1 }\end{array}$ \\
VP2
\end{tabular}

NT: not tested; na: not available 
binant baculovirus B19 antigens (VP2) were developed as enzyme immunoassay. These tests avoid the disadvantages of IFA such as operator interpretation (Nascimento et al. 1998). Biotrin IgM IFA detection has an excellent specificity and sensitivity (Bruu \& Nordbo 1995, Cohen \& Bates 1995, Sloots \& Devine 1996), and the corresponding IgG IFA can be used to determine IgG avidity (Gray et al. 1993).

Our results show that VP1 expressing cells perform better than those expressing VP2 for IgM IFA detection. Compared to MACEIA (Cubel et al. 1994), the sensitivity of VP1 was $70.2 \%$ and VP2 was $52.7 \%$; specificity was $90.9 \%$ for VP1 and $100 \%$ for VP2. Our in house IgM IFA using either VP1 or VP2 is less sensitive than that described by others, but the specificity is higher (Bruu \& Norbo 1995, Cohen \& Bates 1995). Although VP2 is the major capsid component of the B19 viral particle, we believe that VP1 performs better as antigen for IgM IFA because, although VP2 and VP1 sequences overlap in the viral genome (Cotmore \& Tattersall 1984) and VP1 has the same amino acid sequence as VP2, VP1 has additional epitopes on the 227 amino acids unique region that is external to the virus capsid (Rosenfeld et al. 1992, Saikawa et al. 1993). This VP1 unique region also seems responsible for eliciting neutralizing antibodies (Bansal et al. 1993). Among 22 MACEIA negative sera, two were IgM IFA positive using VP1 as antigen but not with VP2. One of these 2 sera, however, was IgM positive for rubella. Cross reactivity between rubella and parvovirus B19 IgM antibodies has been described previously with B19 IgM assays using either native virus antigen (Kurtz \& Anderson 1985), VP2 (Jensen \& Vestergaard 1997), part of VP1/VP2 overlapping region (Fridell et al. 1991, Sloots \& Devine 1996) or VP1 (Bruu \& Nordbo 1995, Cohen \& Bates 1995). This cross reactivity was showed not to be related to the presence of rheumatoid factor (Thomas et al. 1999).

Regarding IgG detection by IFA, we found similar results for both proteins. Compared to EIA (Cubel et al. 1997) the sensitivity of IFA with VP1 was $100 \%$ and with VP2, $98.7 \%$; the specificity with VP1 was $86.6 \%$ and with VP2, 93.3\%. The 2 sera IgG negative by EIA and positive by VP1 IFA, were confirmed as B19 IgG positive by a sensitive and specific anti-VP1 Western-blotting assay (Pinheiro et al. 1997), so the anti-VP1 IgG IFA could be considered $100 \%$ sensitive and specific. Using the same criteria anti-VP2 IgG IFA failed to detec one true B19 IgG positive sample.

The kinetics of epitope type (linear/conformational) specificity in human parvovirus B19 antibody responses were studied by Söderlund et al. (1995b) using recombinant viral capsids as antigen. IgG antibodies of acutely infected patients recognized both conformational and linear antigenic determinants of VP2. IgG to the linear VP2 epitopes disappeared abruptly during late convalescence, whereas $\operatorname{IgG}$ to conformational epitopes persisted. It is not possible to know whether the VP1 epitopes, which maintained their immunoreactivity uniformly during follow-up, were predominantly linear or whether they were conformational but resisted all the proteins denaturants used in this study (Söderlund et al. 1995b). Our IgG IFA results showed no difference between VP1 and VP2 antigens. This could be due to the use of acute infection sera rather than convalescent sera and also because VP2 antigens expressed in Sf9 cells form capsids and so IFA will detect antibodies against conformational as well as linear VP2. Keer et al. (1999) showed that undenatured parvovirus B19 antigens (VP1 or VP2) are essencial for the accurate detection of anti-B19 IgG.

The great difference in sensitivity between IgM and $\mathrm{IgG}$ detection by IFA is clearly shown in Tables II and IV. Standard deviation was less than $50 \%$ of the average of $\mathrm{P} / \mathrm{N}$ ratio for the $\mathrm{IgG}$ test and more than $50 \%$ for the IgM assay, reflecting the low sensitivity of IgM test as compared with the IgG test. Among 35 sera with low $\mathrm{P} / \mathrm{N}$ ratio in MACEIA (2.0 to 3.0), 20 were IgM IFA negative using VP1 and 27 negative using VP2 (Table II). This was not the case with IgG assays (Table IV). The lower sensitivity of IFA IgM detection may be explained by the lower IgM anti-B19 response in children less than 13 years old with EI, as compared with adults with EI or less than 13 years old children with TAC (Mortimer 1996). Nine of our 15 IFA IgM negative patients were children with EI (Table V). Only 2 patients were more than 13 years old, being one in the very early stage of infection (TAC) and she was IgG negative by IFA and EIA.

Applying $\operatorname{IgG}$ avidity test we could diagnose acute infection for 12 of 15 cases that were negative for IgM detection by IFA. For 3 of these patients this diagnosis was only possible because we used VP2 antigen in IFA as well as VP1. Gray et al. (1993), working with 62 patients, found $100 \%$ agreement between anti-VP1 IgG avidity by IF and acute infection previously diagnosed by MACEIA during the first five days after rash. In this paper they used $8 \mathrm{M}$ urea to characterize $\mathrm{IgG}$ avidity by Biotrin IFA. We could not use 8M urea in our experiments because this urea concentration eluted antigen from our slides. Testing different urea concentrations $(4,6$ and $8 \mathrm{M})$ we verified that $6 \mathrm{M}$ urea eluted low avidity $\operatorname{IgG}$ without interfering with the antigen. A lower concentration of urea (4M) did not elute low avidity antibody. Low concentrations of 
urea (e.g. 4.7M), however, have been used for showing low avidity IgG anti-EBV (Weissbrich 1998).

The IgM detection of anti-VP2 antibodies in sera from two patients in which we could not detect anti-VP1 antibodies emphasises the need to use both antigens for B19 IFA. Moreover, we conclude that $\operatorname{IgG}$ avidity test improves the diagnosis of acute B19 infection by IFA but remains less sensitive than our in house IgM capture enzyme immuno assay.

\section{REFERENCES}

Anderson LJ, Tsou C, Parker RA, Chorba TL, Wulff H, Tattersall P, Mortimer PP 1986. Detection of antibodies and antigens of human parvovirus B19 by enzyme-linked immunosorbent assay. J Clin Microbiol 24: 522-526.

Anderson MJ, Higgins PG, Davis LR, Willman JS, Jones SE, Kidd IM, Pattinson JR, Tyrrell DAJ 1985. Experimental parvoviral infection in human. J Infect Dis 152: 257-265.

Bansal GP, Hatfield JA, Dunn FE, Kramer AA, Brady F, Riggin CH, Collet MS, Yoshimoto K, Kajigaya S, Young NS 1993. Candidate recombinant vaccine for human B19 parvovirus. J Infect Dis 167: 10341044.

Brown CS, Sallimans MMM, Noteborn MHM, Weiland HT 1990a. Antigenic B19 coat proteins VP1 and VP2 produced in large quantities in a baculovirus expression system. Virus Res 15: 197-212.

Brown CS, van Bussel MJAWM, Wassenaar ALM, van Elsaker-Niele AMW, Weilland HT, Salimans MMM 1990b. An immunofluorescence assay for the detection of parvovirus B19 IgG and IgM antibodies based on recombinant viral antigen. J Virol Meths 29: 53-62.

Brown CS, Van Lent JWM, Vlak JM, Spaan WJM 1991. Assembly of empty capsids by using baculovirus recombinants expressing human parvovirus B19 structural proteins. J Virol 65: 2702-2706.

Bruu AL, Nordbo AS 1995. Evaluation of five commercial tests for detection of immunoglobulin $\mathrm{M}$ antibodies to human parvovirus B19. J Clin Microbiol 33: 1363-1365.

Cohen BJ, Bates CM 1995. Evaluation of 4 commercial test kits for parvovirus B19-specific IgM. $J$ Virol Meths 55: 11-25

Cohen BJ, Mortimer PP, Pereira MS 1983. Diagnostic assays with monoclonal antibodies for the human serum parvovirus-like virus (SPLV). J Hyg Camb 91: 113-130.

Cotmore SF, Tattersall P 1984. Characterization and molecular cloning of a human parvovirus genome. Science 226: 1161-1165.

Cubel RCN, Alferes ACR, Cohen BJ, Nascimento JP 1994. Application to immunoglobulin M capture hemadherence assays of hemagglutination of monkey erythrocytes by native and recombinant human parvovirus B19 antigens. J Clin Microbiol 32: 19971999.

Cubel RCN, Siqueira MM, Santos EO, Pires MF, Cruz
CMF, Nascimento JP 1997. Human parvovirus B19 infection among exanthematic diseases notified as measles. Rev Soc Bras Med Trop 30: 15-20.

Cubel RCN, Valadão MC, Pereira WV, Magalhães MC, Nascimento JP 1992. Aplastic crisis due to human parvovirus B19 infection in hereditary hemolytic anaemia. Rev Inst Med Trop São Paulo 35: 479-482.

Fridell E, Cohen BJ, Wahren B 1991. Evaluation of a synthetic peptide enzyme linked immunosorbent assay for immunoglobulin $\mathrm{M}$ to human parvovirus B19. J Clin Microbiol 29: 1376-1381.

Gray JJ, Cohen BJ, Desselberger U 1993. Detection of human parvovirus B19 specific IgM and IgG antibodies using a recombinant viral VP1 antigen expressed in insect cells and estimation of time of infection by testing for antibody avidity. J Virol Meth 44: 11-24.

Hicks KE, Cubel RCN, Cohen BJ, Clewley JP 1996. Sequence analysis of a parvovirus B19 isolate and baculovirus expression of the structural and nonstructural proteins. Arch Virol 141: 1319-1327.

Jensen IP, Vestergaard BF 1997. Assessment of a commercial human parvovirus B19 IgM assay. Clin Diag Virol 7: 133-137.

Kajigaya S, Fugii H, Field A, Anderson S, Rosenfeld S, Anderson LJ, Shimada T, Young NS 1991. Self-assembled B19 parvovirus capsids produced in a baculovirus system are antigenically and immunogenecally similar to native virions. Proc Natl Acad Sci USA 88: 4646-4650.

Kerr S, O'Keeffe G, Kilty C, Doyle S 1999. Undenatured parvovirus B19 antigens are essencial for the accurate detection of parvovirus B19 IgG. J Med Virol 57: 179-185.

Kurtz JB, Anderson MJ 1985. Cross-reactions in rubella and parvovirus specific IgM tests. Lancet 2: 1356.

Morinet F, Courouce AM, Galibert F, Perol Y 1991. The use of labeled fusion protein for detection of B19 parvovirus IgM antibodies by an immunocapture test. $J$ Virol Meth 32: 21-30

Mortimer PP 1996. Antibody tests: progress and pitfalls. Clin Diag Virol 5: 131-136.

Nascimento JP, Mistchenko A, Cohen BJ 1998. Laboratory diagnosis of acute human parvovirus B19 infection by specific IgM detection. Rev Inst Med Trop São Paulo 40: 265-266.

Oliveira SA, Brandão AB, Fernandes DG, Bettini LR, Carvalho AB, Pereira ACM, Azevedo KM, Nascimento JP 1996. Human parvovirus B19: clinical and epidemiological study of 24 cases. Rev Inst Med Trop São Paulo 38: 323-327.

Pinheiro MG, Paula WNS, Aguiar FS, Pereira RFA, Nascimento JP 1997. Detecção de anticorpos antiB19 pela técnica de western blotting. Anais do XXXIII Congresso da Sociedade Brasileira de Medicina Tropical, Belo Horizonte, p. 140-141.

Rosenfeld SR, Yoshimoto K, Kajigaya S, Anderson S, Young NS, Field A, Warrener P, Bansal G, Collet MS 1992. The unique region of the minor capsid protein of human parvovirus B19 is exposed on the viral surface. J Clin Invest 89: 2023-2029.

Schwarz TF, Modrow S, Hottenträger B, Höflacher B, 
Jager G, Schartt W, Sumazaki R, Wolf H, Middeldorp J, Roggendorf M, Deinhardt F 1991. New oligopeptide immunoglobulin $\mathrm{G}$ test for human parvovirus B19 antibodies. J Clin Microbiol 29: 431-435.

Saikawa T, Anderson S, Momoeda M, Kajigaya S, Young NS 1993. Neutralizing linear epitopes of B19 parvovirus cluster in the VP1 unique and VP1-VP2 junction regions. J Virol 67: 3004-3009.

Sloots T, Devine PL 1996. Evaluation of four commercial enzyme immunoassays for detection of immunoglobulin M antibodies to human parvovirus B19. Eur J Clin Microbiol Infect Dis 15: 758-761.

Söderlund M, Brown CS, Cohen BJ, Hedman K 1995a. Accurate serodiagnosis of B19 parvovirus infections by measurement of $\mathrm{IgG}$ avidity. J Infect Dis 171: 710-713.

Söderlung M, Brown KE, Meurman O, Hedman K 1992.
Prokaryoticexpression of a VP1 polypeptide antigen for diagnosis by a human parvovirus B19 antibody enzyme immunoassay. J Clin Microbiol 30: 305-311.

Söderlund M, Brown CS, Spaan WJM, Hedman L, Hedman K 1995b. Epitope type-specific IgG responses to capsid proteins VP1 and VP2 of human parvovirus B19. J Infect Dis 172: 1431-1436.

Thomas HIJ, Barrett E, Hesketh LM, Wynne A, Morgan-Capner P 1999. Simultaneous IgM reactivity by EIA against more than one virus in measles, parvovirus B19 and rubella infection. J Clin Virol 14: 107-118.

Weissbrich B 1998. The use of semi-automated EBV IgG avidity determination for the diagnosis of infectious mononucleosis. J Med Virol 54: 145-153.

Young NS 1996. Parvoviruses. In BN Fields, DM Knipe, PM Howley (eds), Virology, 3rd ed. LippincottRaven Publishers, Philadelphia, p. 2199-2220. 